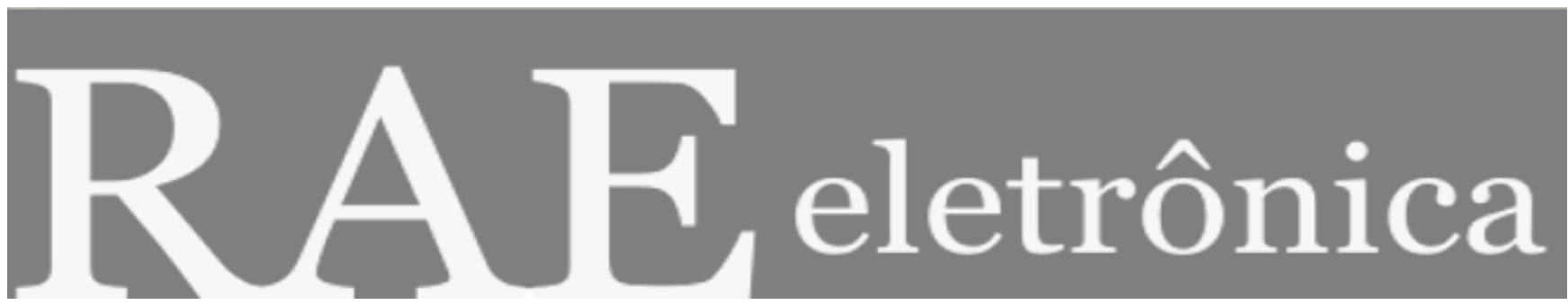

\title{
ERROS DE MARKETING E SUCESSOS
}

Por

Victoria Jones

RAE-eletrônica, Volume 2, Número 1, jan-jun/2003.

http://www.rae.com.br/eletronica/index.cfm?FuseAction=Artigo \&ID=1732\&Secao=RESENHAS\&Volume=2\&Numero=1 $\& \mathrm{Ano}=2003$

CCopyright, 2002, RAE-eletrônica. Todos os direitos, inclusive de tradução, são reservados. É permitido citar parte de artigos sem autorização prévia desde que seja identificada a fonte. A reprodução total de artigos é proibida. Os artigos só devem ser usados para uso pessoal e nãocomercial. Em caso de dúvidas, consulte a redação: redacao@,rae.com.br.

A RAE-eletrônica é a revista on-line da FGV-EAESP, totalmente aberta e criada com o objetivo de agilizar a veiculação de trabalhos inéditos. Lançada em janeiro de 2002, com perfil acadêmico, é dedicada a professores, pesquisadores e estudantes. Para mais informações consulte o site www.rae.com.br/eletronica.

RAE-eletrônica

ISSN 1676-5648

(C2002 Editora: Fundação Getulio Vargas - Escola de Administração

de Empresas de São Paulo.

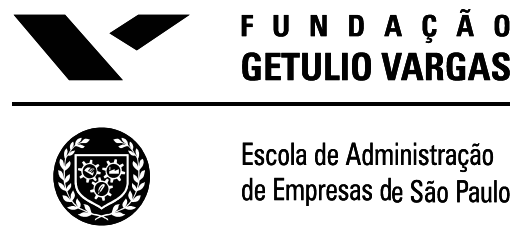




\title{
ERROS DE MARKETING E SUCESSOS
}

\section{Por Victoria Jones}

Professora de Departamento de Mercadologia da FGV-EAESP

E-mail: vjones@,fgvsp.br

\author{
Erros de Marketing e Sucessos \\ De Robert F. Hartley \\ Barueri: Editora Manole Ltda., 2001, 379 p.
}

Imagine Caras magazine crossed with Philip Kotler's Marketing Management textbook. That's the mix of behind-the-scenes voyeurism and practical learning provided by Erros de Marketing $e$ Sucessos. This book by Robert F. Hartley has been popular both in classrooms and boardrooms across the U.S. for the past 25 years. The eighth edition with new cases, classic cases, and up-to-date practical applications is now available in Portuguese (translated by FGV-EAESP Marketing Professor, Ricardo Fasti de Souza). In this book, Hartley goes behind the scenes for some of the most important moments in some of the world's most influential corporations, like Coca Cola, Boeing, McDonald's, IBM and Disney. It is a fun and sometimes tragic read.

Based on the principle of learning from others' mistakes, Hartley focuses most of his attention on marketing errors. He opens with the war between Coca Cola and Pepsi. In the 1970s Pepsi launched a marketing effort called the Pepsi Challenge which publicized blind taste tests that showed consumers preferred the flavor of Pepsi when compared to Coca Cola. In fact, Coca Cola ran their own test and confirmed the results: people did prefer the flavor of their competitor's cola. Pepsi, which had always been far behind Coca Cola, gained rapidly in both market share and brand loyalty. In 1994, a new Coca Cola president launched a radical plan. For the first time in 99 years, Coca Cola changed its flavor. The company spent some US \$4 million for market research with almost 200,000 people. The results showed that people preferred Coca Cola's new flavor, and the board of directors voted unanimously to replace the traditional flavor with "new Coke."

The results were immediate and drastic. The American public felt betrayed and even angry. Coca Cola was about more than flavor for them. After 99 years, it was a part of their national history. Coca Cola was the drink that accompanied American soldiers through two world wars. It was the drink of the 1950s diners and drive-ins. In the turmoil of the 1960s it was the drink that taught "the world to sing." The new Coke held none of these associations for consumers and they protested with as many as 5,000 angry phone calls to the company every day. Coca Cola responded to the custumor complaints and reintroduced the original "Coca Cola Classic" flavor. Amazingly, the company recovered quickly from its mistake and consumers returned gratefully to the company buying both the old and new flavors.

Coca Cola and its long-standing battle with Pepsi have spawned a variety of popular books ${ }^{1}$ but Hartley squeezes out a marketing lesson in a few efficient pages. He lays the blame on the market

1 ENRICO, Roger, KORNBLUTH, Jesse. The Other Guy Blinked: And Other Dispatches from the Cola Wars. Bantam Books, 1988

OLIVER, Thomas. Real Coke, the Real Story. Random House Trade, 1986. 
research which failed to consider the emotional ties to the product. Another mistake he cites is swapping one product for another rather than adding a new flavor to the line of products.

In the next section of the "Cola Wars" chapter, Hartley discusses Pepsi's struggles to establish its brand against Coca Cola in Brazil. This is one of the few sections of Hartley's book with direct reference to Latin America. In fact, this is one of the book's greatest weaknesses for a Brazilian reader: it focuses almost exclusively on U.S. companies doing business in North America. The only non-U.S. company featured is the French company Perrier, but the case focuses on their U.S. operations. Seven cases have some international aspect including Nike, Disney, Boeing, Maytag, and Wal-Mart. And, while most of the companies are well-known in Brazil, the focus on only one market forces readers to evaluate for themselves whether the lessons learned in the U.S. apply to markets in South America.

In fact, one of the cases is about a company that failed to adapt its strategies appropriately to a different national market. Euro Disney was the company's second international theme park. The tremendous success of Disney's park in Japan made the company optimistic about success in other world regions. According to Hartley, the company entered too optimistically with huge debts and break-even estimates based on many more visitors than actually came. Assuming demand inelasticity and weak competition, they set admission prices significantly above those in the U.S. To keep up its wholesome image, the company also refused to sell alcoholic drinks. But this policy, based on a segment of U.S. cultural values, merely frustrated Europeans who commonly enjoy wine with family meals. The very different results of Disney's strategies in Japan and Europe have been studied more deeply by researcher Mary Yoko Brannen who explains the cultural shifts and required adaptations through her theory of "recontextualization." ${ }^{2}$ Disney eventually learned to adapt to the European context and is now the top tourist attraction in France, even attracting more visitors than the Cathedral of Notre Dame. Once again optimistic, Disney is now developing plans to open a theme park in Hong Kong in 2005.

For those who have used cases in their marketing classes, either as faculty or as students, it is important to make a point about the type of cases used in this book. Each chapter begins with a story outlining the challenges facing a particular company followed by the actions taken and the results of those actions. These are not the classic Harvard-style cases in which the reader is taken to the moment of decision and left to make that decision as if he was the manager. The reader is not left to wrestle with difficult issues and discuss alternative strategies. He is told exactly what decisions were made and what happened as a result. But there is still plenty of rich learning in this book either for classroom use or for individual reading. In fact, unlike Harvard-style cases, a reader can learn from this book at the beach as easily as in a classroom. After telling each story, Hartley provides an analysis and then a section that lists and elaborates on the lessons learned. He closes each chapter with questions and exercises that faculty can use to compliment their lectures and textbooks.

PENDERGRAST, Mark. For God Country and Coca Cola: The Definitive History of the Great American Soft Drink and thr Company that Makes It. Basic Books, 2000.

2 BRANNEN, Mary Yoko, WILSON, James M. III. Recontextualization and Internationalization: Lessons Learned in Transcultural Materialism from the Walt Disney Company. CEMS Business Review, pp 97-110, Vol. 1, 1996

BRANNEN, Mary Yoko. "Bwana Mickey": Reconstructing Cultural Consumption at Tokyo Disneyland. In Remade in Japan, Joseph Tobin (ed.). Yale University Press, 1992. 
"De que moda voce motivaria os funcionarios para que dessem prioridade ao servico ao consumidor?" This is one of the end-of-chapter questions that draws readers more deeply into the challenges faced by Continental airlines. As one part of a group of companies, Continental was treated less as a service provider than as a trading piece in stock market games. The extreme focus on finances ruptured relationships with employees and clients. Objective ratings of airline service ranked Continental near the bottom in all major categories. Used in this book as an example of a successful turnaround, the story changes with the arrival of Gordon Bethune who focused on the human side of the business. For example, he simplified corporate "rules" so that employees could respond quickly to meet customer needs. He also rewarded employees for providing services valued by customers. For example, every employee received a bonus for on-time arrivals. Some of the lessons Hartley draws from the case are that employee relations are important, that inconsistent policies create vulnerability, and that companies can change quickly (Hartley showed strong financial returns in his first year).

Erros de Marketing e Sucessos is organized in six parts, each with two to seven cases that illustrate the theme. The first section focuses on marketing wars between powerful competitors including the tennis shoe manufacturers Nike and Reebok, airplane manufacturers Airbus and Boeing, and fast food giants McDonald's and Burger King. The second and third sections applaud great recoveries and successful crisis management. Continental Airlines and IBM are the classic cases used to illustrate recoveries. Crisis management shows how to companies responded to apparent product contamination. They are the cases of Johnson and Johnson's Tylenol and Perrier's sparkling water. It also looks at Met Life in the insurance industry and United Way in the third sector. Marketing management errors fill the next section with stories from diverse companies such as Planet Hollywood restaurants, Coors beer, Maytag appliances and Euro Disney. Three companies are praised in the section on exceptional successes: Vanguard in financial investments, Southwest in low-price air travel and Wal Mart in retail. The last chapter is especially timely after the scandals that shamed several powerful U.S. corporations though it predates the crises and does not touch the now infamous companies. The chapter on errors in ethics looks at price fixing of agricultural products by ADM and also at the policies of the tobacco industry.

This book is both interesting and informative. It is easy-to-read and rich in lessons that can be applied to marketing challenges. The focus on errors is balanced by the lessons for success. As Hartley himself explains, "Os erros podem se tornar ferramentas de ensino e evitar que enganos similares se repitam." 